\title{
PERAMALAN PENCEMARAN UDARA DI KOTA SURABAYA MENGGUNAKAN METODE DSARIMA DENGAN PENDEKATAN PERCENTILE ERROR BOOTSTRAP
} $(P E B)$

\author{
Novi Koesoemaningroem*1, Endroyono², Supeno Mardi Susiki Nugroho ${ }^{3}$ \\ ${ }^{1,2,3}$ Fakultas Teknologi Elektro dan Informatika Cerdas, Institut Teknologi Sepuluh Nopember Surabaya \\ Email: ${ }^{1}$ novi.19071@mhs.its.ac.id, ${ }^{2}$ endroeleven@gmail.com, ${ }^{3}$ mardi@its.ac.id \\ *Penulis Korespondensi
}

(Naskah masuk: 29 Juni 2021, diterima untuk diterbitkan: 18 Oktober 2021)

\begin{abstract}
Abstrak
Peramalan pencemaran udara yang akurat diperlukan untuk mengurangi dampak pencemaran udara. Peramalan yang belum akurat akan berdampak kurang efektifnya tindakan yang dilakukan untuk mengantisipasi dampak pencemaran udara. Sehingga diperlukan sebuah pendekatan yang dapat mengetahui keakuratan plot data hasil peramalan. Penelitian ini dilakukan dengan tujuan melakukan peramalan pencemaran udara berdasarkan parameter $\mathrm{PM}_{10}, \mathrm{NO}_{2}, \mathrm{CO}, \mathrm{SO}_{2}$, dan $\mathrm{O}_{3}$ dengan metode DSARIMA. Data dalam penelitian ini sebanyak 8.760 data yang berasal dari Dinas Lingkungan Hidup Kota Surabaya. Berdasarkan hasil peramalan selama 168 jam kadar parameter $\mathrm{PM}_{10}, \mathrm{NO}_{2}, \mathrm{SO}_{2}$ dan $\mathrm{O}_{3}$ cenderung menurun. Hasil peramalan selama 168 jam dengan menggunakan DSARIMA memberikan hasil peramalan yang nilainya mendekati data aktual terbukti dari polanya yang sesuai atau mirip dengan grafik plot data aktual dengan hasil ramalan. Dengan pendekatan PEB, selisih antara data aktual dan data ramalan kecil dan plot grafik PEB mengikuti plot grafik di data aktual, sehingga dapat dikatakan bahwa model sudah sesuai. Hasil akurasi terbaik yang dihasilkan adalah model DSARIMA dengan RMSE terkecil 0,59 didapatkan dari parameter CO yaitu $\operatorname{ARIMA}(0,1,[1,2,3])(0,1,1)^{24}(0,1,1)^{168}$.
\end{abstract}

Kata kunci: pencemaran udara, peramalan, DSARIMA, Percentile Error Bootstrap (PEB)

\section{FORECASTING AIR POLLUTION IN SURABAYA CITY USING DSARIMA METHOD WITH PERCENTILE ERROR BOOTSTRAP (PEB) APPROACH}

Abstract

Accurate air pollution forecasting is needed to reduce the impact of air pollution. Inaccurate forecasting will result in less effective actions taken to anticipate the impact of air pollution. So we need an approach that can determine the accuracy of the forecast data plot. This research was conducted with the aim of forecasting air pollution based on the $\mathrm{PM}_{10}, \mathrm{NO}_{2}, \mathrm{CO}$, ${ }_{\mathrm{SO}}$, and $\mathrm{O}_{3}$ parameters using the DSARIMA method. The data in this study were 8.760 data from the Surabaya City Environmental Service. Based on the results of forecasting for 168 hours, the levels of $\mathrm{PM}_{10}, \mathrm{NO}_{2}, \mathrm{SO}_{2}$, and $\mathrm{O}_{3}$ parameters tend to decrease. Forecasting results for 168 hours using DSARIMA provide forecasting results whose values are close to the actual data as evidenced by the pattern that matches or is similar to the actual data plot graph with the forecast results. With the PEB approach, the difference between the actual data and the forecast data is small and the PEB graph plot follows the graph plot in the actual data, so it can be said that the model is appropriate. The best accuracy result is DSARIMA with the smallest RMSE 0,59 obtained from the CO parameter, namely $\operatorname{ARIMA}(0,1,[1,2,3])(0,1,1)^{24}(0,1,1)^{168}$.

Keywords: air pollution, forecasting, DSARIMA, Percentile Error Bootstrap (PEB)

\section{PENDAHULUAN}

Jutaan orang di dunia meninggal akibat pencemaran udara, hal ini disebutkan dalam laporan WHO pada tahun 2018 (Hamami \& Dahlan, 2020). Pencemaran udara juga merupakan salah satu masalah yang dihadapi di Kota Surabaya. Hal ini dipicu dengan terjadinya perubahan komposisi pada udara dibandingkan dengan keadaan normal. Pencemaran udara dipicu oleh masuknya zat atau materi yang masuk ke dalam udara sehingga menyebabkan kualitas udara menurun. Kegiatan manusia yang memicu pencemaran udara antara lain berasal dari kendaraan bermotor, industri, pembakaran sampah, pertanian, penambangan, dan pembangkit listrik. Selain itu pencemaran udara dapat disebabkan oleh faktor alam di antaranya gunung meletus, kebakaran hutan dan gas metana yang dihasilkan dari peternakan. Pencemaran udara 
merupakan faktor yang sangat mempengaruhi kesehatan manusia (Wahyu, 2018)

Berdasarkan penelitian (Dua et al., 2019) menyebutkan bahwa $95 \%$ orang hidup dengan menghirup udara yang tercemar. Udara yang tercemar udara akan memperpendek harapan hidup manusia. Laporan dari State of Global Air (SOGA) 2019 yang diterbitkan oleh Health Effect Institute di Amerika dan Universitas British Columbia di Kanada menyebutkan bahwa polusi udara merupakan faktor penyebab ke-5 paling besar yang memperpendek usia manusia. Salah satu faktor yang berpengaruh terhadap pencemaran udara adalah adanya aktifitas manusia yang melakukan urbanisasi dan pertumbuhan industri. Hal ini menyebabkan jumlah kendaraan bermotor dan pembakaran bahan bakar fosil juga meningkat, akibatnya kualitas udara menurun. Kenaikan tingkat pencemaran udara menyebabkan penyakit berbahaya seperti paru-paru, jantung, asma dan infeksi saluran pernafasan akut (Madaan et al., 2019). Pencemaran udara juga menyebabkan hujan asam yang dapat merusak hutan dan berpengaruh terhadap makhluk hidup lainnya (Zhu \& Hu, 2019).

Berbagai upaya dilakukan untuk mengurangi dampak buruk dari pencemaran udara. Langkah pertama yang dapat dilakukan untuk mengontrol pencemaran udara adalah dengan menggunakan metode peramalan yang dapat meramalkan kondisi pencemaran udara (Tomar et al., 2020). Pemanfaatan teknologi di bidang komputer dapat digunakan untuk melakukan peramalan pencemaran udara sehingga dapat membantu menjadikan kehidupan yang lebih baik. Kualitas hidup dipengaruhi oleh kualitas udara (Mahajan et al., 2017). Peramalan dapat berfungsi sebagai peringatan dini terhadap akibat yang ditimbulkan dari pencemaran udara. Peramalan yang baik dapat memberikan gambaran kondisi pencemaran udara di waktu yang akan datang. Hal ini bermanfaat untuk melakukan tindakan antisipasi agar dampak pencemaran udara tidak menjadi semakin buruk bagi kesehatan manusia.

Namun metode peramalan pencemaran udara yang akurat masih belum sepenuhnya didapatkan. Metode peramalan yang akurat sangatlah berarti (Zhu \& Hu, 2019). Berbagai metode diuji coba untuk mendapatkan metode peramalan yang akurat. Ada berbagai macam metode peramalan pencemaran udara telah dilakukan antara lain ARMA, ARIMA, ANN, LSTM (Deepthi et al., 2020). Pada penelitian peramalan pencemaran udara di India (Abhilash et al., 2018) menggunakan tiga parameter yaitu $\mathrm{NO}_{2}, \mathrm{PM}_{10}$ and $\mathrm{SO}_{2}$, dengan menggunakan metode ARIMA untuk membuat peramalan jangka pendek dengan data yang akurat, namun ARIMA hanya dapat menangkap model linier stasioneritas, dan linieritas. Syarat untuk membuat model prediksi yang akurat adalah data yang stasioner. Penelitian peramalan pencemaran udara (Tsai, 2018) menggunakan metode RNNLSTM pada parameter $\mathrm{PM}_{2,5}$, hasil yang diperoleh nilai tahunan rata-rata $\mathrm{PM}_{2,5}$ dan di sebagian besar stasiun RMSE berukuran besar disebabkan karena karakteristik polusi udara yang mempengaruhi lokasi tersebut. Sedangkan pada penelitian peramalan indeks kualitas udara (Haizum et al., 2019) metode hybrid antara SARIMA dengan jaringan syaraf tiruan menghasilkan akurasi yang berdasarkan RMSE adalah 6,81.

Berdasarkan beberapa penelitian yang telah dilakukan sebelumnya, pada penelitian ini mencoba untuk memberikan alternatif metode peramalan dengan menggunakan metode DSARIMA (Double Seasonal Autoregressive Integrated Moving Average) dengan pendekatan PEB yang diharapkan mendapatkan model peramalan dengan nilai RMSE (Root Mean Square Error) yang terkecil.

Posisi penelitian ini dibandingkan dengan riset sebelumnya adalah penggunaan model terbaik hasil dari metode DSARIMA serta menerapkan pendekatan Percentile Error Bootstrap (PEB) terhadap kandungan parameter $\mathrm{PM}_{10}, \mathrm{CO}, \mathrm{NO}_{2}, \mathrm{SO}_{2}$, dan $\mathrm{O}_{3}$.

\section{METODE PENELITIAN}

Dalam penelitian ini dilakukan beberapa tahapan yang meliputi proses pengumpulan sampai dengan pengolahan data. Tahapan penelitian dapat dijelaskan dalam beberapa langkah sebagai berikut:

\subsection{Pengumpulan Data}

Data diperoleh dari hasil pengamatan yang dilakukan oleh Dinas Lingkungan Hidup Kota Surabaya. Namun pengumpulan data selama beberapa tahun ditemukan banyak data yang kosong sehingga data yang diolah hanya data selama satu tahun yang paling lengkap. Data yang dikumpulkan dalam format excel seperti Tabel 1 .

Tabel 1. Contoh Data $\mathrm{PM}_{10}$ dari DLH

\begin{tabular}{cccrr}
\hline Waktu & SUF 4 & SUF 5 & SUF 6 & SUF 7 \\
\hline $0: 30$ & - & - & 28,43 & 45,00 \\
$1: 00$ & - & - & 29,00 & 51,13 \\
$1: 30$ & - & - & 32,36 & 52,00 \\
$2: 00$ & - & - & 33,00 & 73,80 \\
$2: 30$ & - & - & 35,63 & 76,00 \\
$3: 00$ & - & - & 36,00 & 87,20 \\
$3: 30$ & - & - & 40,51 & 88,00 \\
$4: 00$ & - & - & 41,00 & 99,70 \\
\hline
\end{tabular}

\subsection{Dataset}

Data yang digunakan pada penelitian ini adalah data selama satu tahun (bulan Agustus 2017 sampai dengan Juli 2018). Data yang diolah adalah data per jam dengan jumlah sebanyak 8.760 jam. Data tersebut dipilih karena memiliki data yang paling lengkap jika dibandingkan dengan data di tahun yang lainnya yang memiliki banyak data kosong. 
Dari data tersebut dibagi menjadi dua yaitu data latih sebanyak 8.592 jam dan data uji 168 jam.

\subsection{Preprocessing}

Pada tahap ini dilakukan proses seleksi dan pembersihan data yang rusak serta memperbaiki data yang kosong dengan metode interpolasi seperti dalam Tabel 2 dan Tabel 3 agar data dapat digunakan pada proses pengolahan selanjutnya. Kemudian dilakukan plot data dengan bantuan software Minitab untuk membuat plot data deret waktu agar telihat pola datanya.

\begin{tabular}{rcccr}
\multicolumn{5}{c}{ Tabel 2. Data sebelum Interpolasi } \\
\hline $\mathbf{P M}_{\mathbf{1 0}}$ & $\mathbf{C O}$ & $\mathbf{N O}_{\mathbf{2}}$ & $\mathbf{S O}_{\mathbf{2}}$ & $\mathbf{O}_{\mathbf{3}}$ \\
\hline 25,41 & 2,06 & 38,97 & 5,85 & 76,69 \\
22,56 & 1,05 & 35,96 & 2,62 & 44,94 \\
19,70 & 1,13 & 44,77 & 2,48 & 40,61 \\
17,65 & 0,99 & 44,50 & 1,55 & 40,26 \\
$\ldots \ldots \ldots$ & 0,62 & 29,20 & 0,84 & 20,73 \\
12,00 & $\ldots \ldots \ldots$ & 39,07 & 1,78 & 14,87 \\
9,06 & 1,49 & 62,99 & 2,58 & $\ldots \ldots \ldots$ \\
10,53 & 1,60 & 48,54 & 3,36 & 11,59 \\
\hline \multicolumn{5}{c}{} \\
\hline \multicolumn{5}{c}{ Tabel 3. Data sesudah Interpolasi } \\
\hline $\mathbf{P M}$ & $\mathbf{C O}$ & $\mathbf{N O} \mathbf{O}_{\mathbf{2}}$ & $\mathbf{S O} \mathbf{2}$ \\
\hline 25,41 & 2,06 & 38,97 & 5,85 & $\mathbf{\mathbf { O } _ { 3 }}$ \\
22,56 & 1,05 & 35,96 & 2,62 & 44,69 \\
19,70 & 1,13 & 44,77 & 2,48 & 40,61 \\
17,65 & 0,99 & 44,50 & 1,55 & 40,26 \\
14,82 & 0,62 & 29,20 & 0,84 & 20,73 \\
12,00 & 1,06 & 39,07 & 1,78 & 14,87 \\
9,06 & 1,49 & 62,99 & 2,58 & 13,23 \\
10,53 & 1,60 & 48,54 & 3,36 & 11,59 \\
\hline \multicolumn{5}{c}{}
\end{tabular}

\subsection{Uji Stasioneritas Data}

Pada tahap ini dilakukan pengujian data apakah bersifat stasioner dalam varian dan dalam mean. Apabila data tidak stasioner dalam varian maka dilakukan transformasi Box-Cox, bila data tidak stasioner dalam mean maka dilakukan differencing (metode pembedaan).

\subsection{Membuat Plot ACF PACF}

Pada tahap ini membuat plot ACF (Auto Correlation Function) dan PACF (Partial Auto Correlation Function untuk menentukan model tentatif atau kandidat yang akan dipilih untuk melakukan peramalan yang terbaik.

\subsection{Estimasi Parameter}

Pada tahap ini melakukan tahapan Box-Jenkins dengan cara mengecek signifikansi parameter, membuang parameter yang tidak signifikan dan overfitting (data yang digunakan untuk pelatihan atau membuat model adalah data yang terbaik).

\subsection{Uji Residual}

Tahap ini dilakukan apabila parameter model yang dipilih telah sesuai, maka dapat dilanjutkan dengan proses pengujian diagnosa residual, namun jika parameter model belum sesuai maka proses akan diulang kembali dengan penentuan model peramalan sampai dengan memperoleh data signifikan. Pada proses pengujian diagnosa residual dilakukan dengan menggunakan uji white noise atau uji distribusi normal.

\subsection{Peramalan Data}

Tahap ini dilakukan jika uji diagnosa residual sudah memenuhi syarat uji white noise atau distribusi normal. Peramalan data dilakukan jika sudah mendapatkan model terbaik dari tiap parameter, sehingga dapat dilanjutkan ke tahap analisa data, namun bila belum memenuhi syarat yang ditentukan maka proses akan diulang dari tahap menentukan model yang sesuai. Peramalan dilakukan dengan metode DSARIMA. Adapun bentuk umum dari model umum DSARIMA (Chrisdayanti \& Suharsono, 2015) dapat dituliskan dengan persamaan (1):

$\emptyset_{p}(\mathrm{~B}) \emptyset\left(\mathrm{B}^{s_{1}}\right) \emptyset_{p 2}\left(\mathrm{~B}^{s_{2}}\right)(1-B)^{d}(1$

$\left.-\mathrm{B}^{s_{1}}\right)\left(1-\mathrm{B}^{s_{1}}\right)^{D}(1$

$\left.-\mathrm{B}^{s_{2}}\right)^{D_{2}} Z_{t=\theta_{q}}(B) \theta_{Q 1}\left(\mathrm{~B}^{s_{1}}\right) \theta_{Q 2}\left(\mathrm{~B}^{s_{2}}\right) a_{t}$

$P 1$ : orde dari seasonal 1 autoregressive (AR)

$P 2$ : orde dari seasonal 2 autoregressive (AR)

$Q 1$ : orde dari seasonal 1 moving average (MA)

Q2 : orde dari seasonal 2 moving average (MA)

$D 1$ : orde dari seasonal 1 differencing

D2 : orde dari seasonal 2 differencing

$s 1$ : periode seasonal 1

$s 2$ : periode seasonal 2

\subsection{Memilih Model yang Terbaik}

Pemilihan model yang terbaik dilakukan dengan didasarkan pada nilai Root Mean Square Error (RMSE) yang paling kecil dari beberapa model tentatif yang terpilih. Identifikasi model DSARIMA berdasarkan grafik ACF dan PACF.

\subsection{Melakukan Peramalan Tahap ke Depan}

Setelah didapatkan model yang terbaik dengan RMSE terkecil dari tiap parameter, maka dilakukan peramalan pada tahap ke depan. Hasil peramalan dapat digunakan sebagai bahan masukan ke dinas terkait untuk melakukan kebijakan terkait pengendalian terhadap pencemaran udara.

\subsection{Menerapkan Percentille Error Bootstrap (PEB)}

PEB diterapkan untuk memenuhi asumsi distribusi normal pada residual plot grafik hasil ramalan. Jika plot data berada dalam batas atas dan bawah, maka dapat disimpulkan bahwa hasil ramalan berdistribusi normal. 
Pencemaran udara dapat diukur berdasarkan standar baku mutu udara yang telah ditetapkan pemerintah (Peraturan Pemerintah Republik Indonesia, 1999). Dalam standar tersebut tercantum baku mutu untuk tiap parameter yang dapat dilihat seperti pada Tabel 4 .

Tabel 4. Baku Mutu Udara Menurut PP No.41 Tahun 1999

\begin{tabular}{crr}
\hline Parameter & Waktu & Baku Mutu \\
\hline $\mathrm{PM}_{10}$ & 24 Jam & $150 \mu \mathrm{g} / \mathrm{m}^{3}$ \\
$\mathrm{CO}$ & 1 Jam & $30.000 \mu \mathrm{g} / \mathrm{m} 3$ \\
& 24 Jam & $10.000 \mu \mathrm{g} / \mathrm{m} 3$ \\
$\mathrm{NO}_{2}$ & 1 Jam & $400 \mu \mathrm{g} / \mathrm{m} 3$ \\
& 24 Jam & $150 \mu \mathrm{g} / \mathrm{m} 3$ \\
& 1 Tahun & $100 \mu \mathrm{g} / \mathrm{m} 3$ \\
$\mathrm{SO}_{2}$ & 1 Jam & $900 \mu \mathrm{g} / \mathrm{m} 3$ \\
& 24 Jam & $365 \mu \mathrm{g} / \mathrm{m} 3$ \\
& 1 Tahun & $60 \mu \mathrm{g} / \mathrm{m} 3$ \\
$\mathrm{O}_{3}$ & 1 Jam & $235 \mu \mathrm{g} / \mathrm{m} 3$ \\
& 1 Tahun & $50 \mu \mathrm{g} / \mathrm{m} 3$ \\
\hline
\end{tabular}

\section{HASIL DAN PEMBAHASAN}

\subsection{Statistik Deskriptif}

Sebelum dilakukan analisis data yang berhubungan dengan peramalan, langkah yang harus dilakukan terlebih dahulu adalah melakukan statistik deskriptif. Kegiatan ini merupakan analisis statistika untuk menggali informasi pada data. Dalam penelitian ini, statistik deskriptif yang digunakan adalah rata-rata, median, standar deviasi, nilai maksimum dan nilai minimum. Statistik deskriptif kandungan $\mathrm{PM}_{10}, \mathrm{CO}, \mathrm{NO}_{2}, \mathrm{SO}_{2}$, dan $\mathrm{O}_{3}$, ditunjukkan pada Tabel 5.

Tabel 5. Statistik Deskriptif Parameter

\begin{tabular}{ccrcrr}
\hline $\begin{array}{c}\text { Para- } \\
\text { meter }\end{array}$ & $\begin{array}{c}\text { Rata- } \\
\text { rata }\end{array}$ & Median & $\begin{array}{c}\text { Standar } \\
\text { Deviasi }\end{array}$ & $\begin{array}{l}\text { Nilai } \\
\text { Max }\end{array}$ & $\begin{array}{l}\text { Nilai } \\
\text { Min }\end{array}$ \\
\hline $\mathrm{PM}_{10}$ & 66,61 & 54 & 52,55 & 199 & 0 \\
$\mathrm{CO}$ & 35,48 & 33,82 & 17,03 & 125,86 & 2,14 \\
$\mathrm{NO}_{2}$ & 14,71 & 8,61 & 14,78 & 136,71 & 0 \\
$\mathrm{SO}_{2}$ & 11,28 & 9,45 & 8,39 & 80,79 & 0,23 \\
$\mathrm{O}_{3}$ & 1,53 & 1,33 & 1,09 & 10,80 & 0 \\
\hline
\end{tabular}

Dari Tabel 5 dapat disimpulkan bahwa parameter yang memiliki rata-rata kandungan tertinggi dan capaian nilai maksimum paling tinggi di antara parameter yang lain adalah PM10. Standar deviasi yang tinggi menunjukkan bahwa data PM10 memiliki varian data yang besar.

Berdasarkan Tabel 6 model untuk peramalan kandungan CO memiliki nilai RMSE yang paling kecil dibandingkan dengan parameter yang lainnya yaitu 0,59 . Hal ini disebabkan data hasil pengamatan yang digunakan sebagai data pelatihan cukup baik karena datanya paling lengkap (tidak banyak) data yang kosong. Penyebaran data (variasi data) juga kecil sehingga menghasilkan nilai RMSE yang kecil.
Sedangkan nilai RMSE yang paling besar dihasilkan dari model parameter $\mathrm{PM}_{10}$ yaitu 38,58. Hal ini dipicu karena data hasil pengamatan banyak yang kosong, selain itu parameter $\mathrm{PM}_{10}$ memiliki penyebaran data yang besar yang artinya menunjukkan bahwa nilai rata-rata $\mathrm{PM}_{10}$ menyebar jauh dan memiliki variasi data yang banyak.

\subsection{Pemodelan DSARIMA tiap Parameter}

Berdasarkan langkah-langkah yang sudah dilakukan dalam pembuatan model tiap parameter, dapat disusun model tentatif dari tiap-tiap parameter seperti terlihat pada Tabel 6 .

\begin{tabular}{clr}
\multicolumn{3}{c}{ Tabel 6. Model Tentatif tiap Parameter } \\
\hline $\begin{array}{c}\text { Para- } \\
\text { meter }\end{array}$ & \multicolumn{1}{c}{ Model Tentatif } & RMSE \\
\hline PM $_{10}$ & ARIMA $(1,1,[1,9,11])(0,1,1)^{24}(1,1,0)^{168}$ & 38,58 \\
& ARIMA $(1,1,1)(0,1,1)^{24}(1,1,0)^{168}$ & 45,07 \\
& & \\
$\mathrm{CO}$ & ARIMA $(0,1,[1,2,3])(0,1,1)^{24}(0,1,2)^{168}$ & 0,60 \\
& ARIMA $(0,1,[1,2,3])(0,1,1)^{24}(0,1,1)^{168}$ & 0,59 \\
$\mathrm{NO}_{2}$ & ARIMA $(0,1,[1,2,3])(0,1,1)^{24}(1,1,1)^{168}$ & 12,69 \\
& ARIMA $(0,1[1,2,3])(0,1,1)^{24}(0,1,1)^{168}$ & 12,77 \\
& ARIMA $(0,1[1,2,3])(0,1,1)^{24}(1,1,0)^{168}$ & 11,44 \\
$\mathrm{SO}_{2}$ & ARIMA & \\
& A $[1,2,4,21,22,23], 1,0)(0,1,1)^{24}(0,1,1)^{168}$ & 9,38 \\
& ARIMA $([1,2,4,23], 1,0)(0,1,1)^{24}(0,1,1)^{168}$ & 9,10 \\
& ARIMA $([1,2,4], 1,0)(0,1,1)^{24}(0,1,1)^{168}$ & 9,23 \\
& & \\
$\mathrm{O}_{3}$ & ARIMA $(0,1[1,2,3,4,22])(0,1,2)^{24}(0,1,1)^{168}$ & 14,55 \\
& ARIMA $(0,1[1,2,3,22,23])(0,1,2)^{24}(0,1,1)^{168}$ & 15,25 \\
\hline
\end{tabular}

Dari model tentatif yang terbentuk kemudian dipilih model terbaik berdasarkan nilai kesalahan terkecil (RMSE) seperti pada Tabel 7.

Tabel 7. Model Terbaik tiap Parameter

\begin{tabular}{clr}
\hline $\begin{array}{c}\text { Para- } \\
\text { meter }\end{array}$ & \multicolumn{1}{c}{ Model } & RMSE \\
\hline PM10 & ARIMA $(1,1,[1,9,11])(0,1,1)^{24}(1,1,0)^{168}$ & 38,58 \\
CO & ARIMA $(0,1,[1,2,3])(0,1,1)^{24}(0,1,1)^{168}$ & 0,59 \\
NO2 & ARIMA $(0,1,[1,2,3])(0,1,1)^{24}(1,1,0)^{168}$ & 11,44 \\
SO2 & ARIMA & \\
& $([1,2,4,23], 1,0)(0,1,1)^{24}(0,1,1)^{168}$ & 9,10 \\
O3 & $\begin{array}{l}\text { ARIMA } \\
(0,1,[1,2,3,4,22])(0,1,2)^{24}(0,1,1)^{168}\end{array}$ & 14,55 \\
\hline
\end{tabular}

\subsection{Peramalan tiap Parameter}

Peramalan selama 168 jam ke depan (satu minggu) periode 25-31 Juli 2018 dilakukan dengan menggunakan model peramalan yang terbaik dari tiap parameter. Grafik hasil peramalan dapat dilihat pada Gambar 1. 


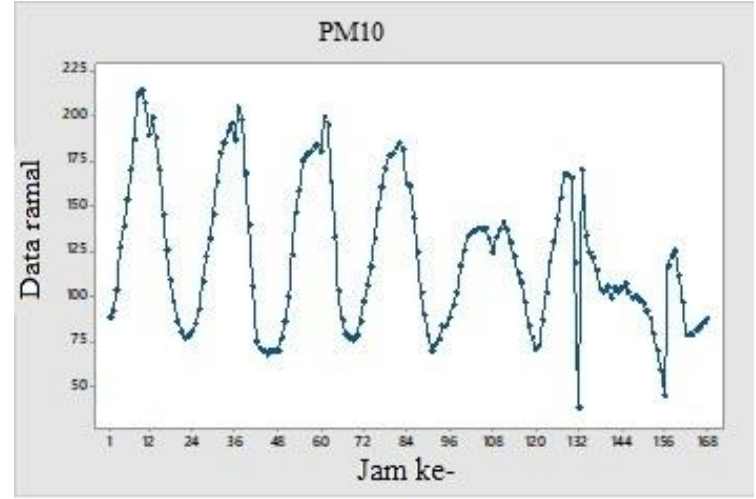

(a) $\mathrm{PM}_{10}$

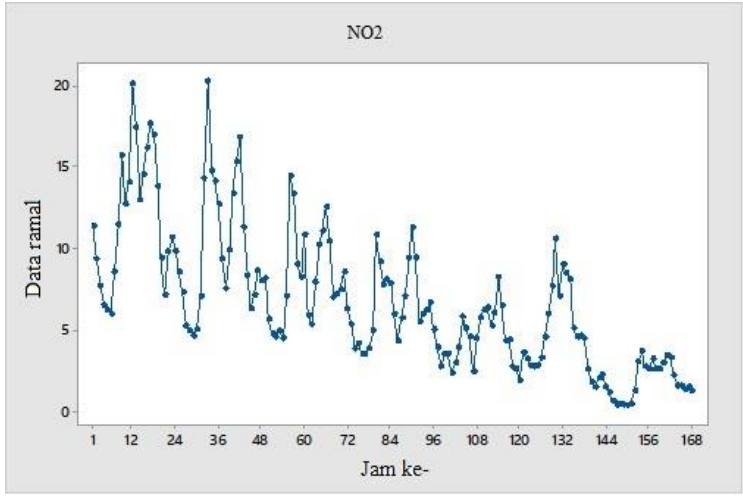

(c) $\mathrm{NO}_{2}$

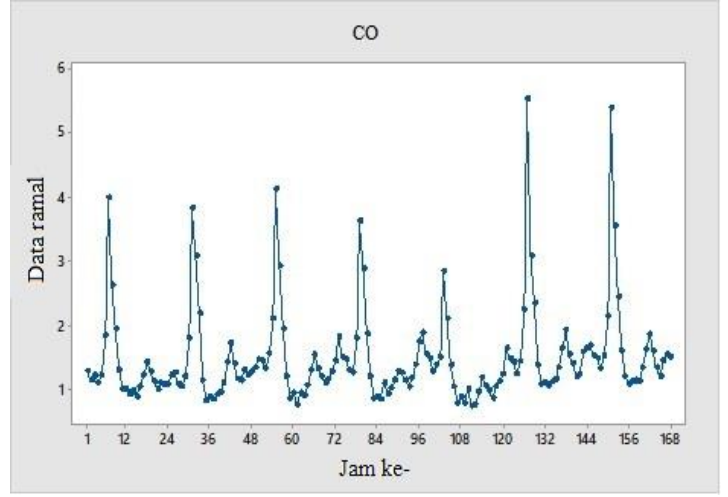

(b) $\mathrm{CO}$

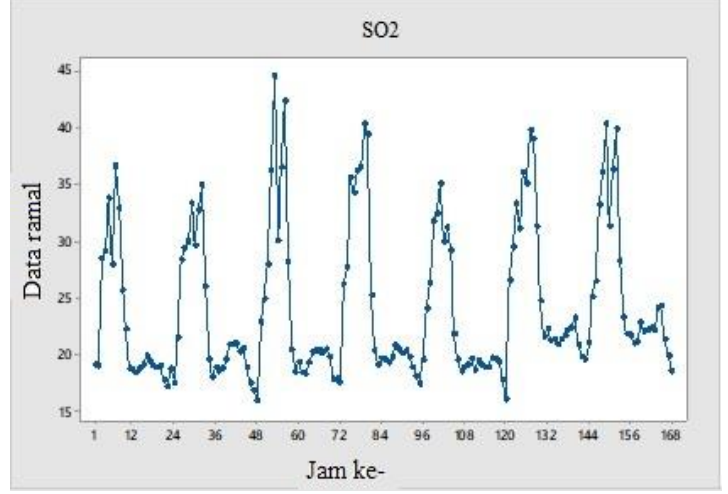

(d) $\mathrm{SO}_{2}$

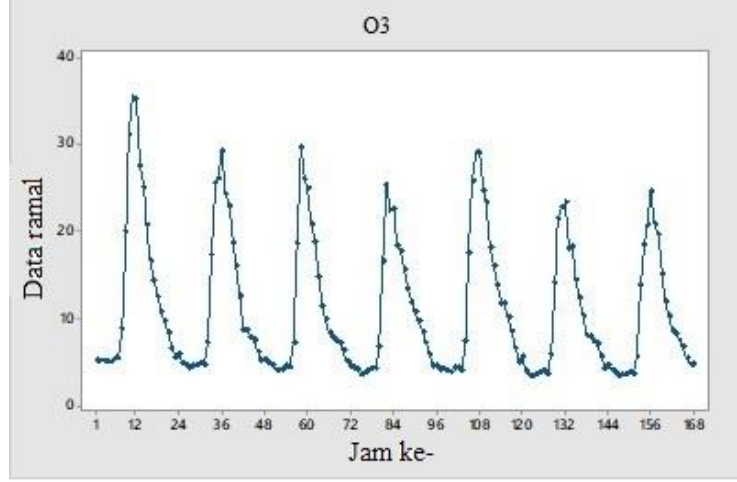

(e) $\mathrm{O}_{3}$

Gambar 1. Hasil Peramalan tiap Parameter

Berdasarkan Gambar 1 tentang hasil peramalan tiap parameter pencemar udara menunjukkan kecenderungan bahwa kandungan untuk parameter $\mathrm{PM}_{10}, \mathrm{CO}, \mathrm{NO}_{2}, \mathrm{SO}_{2}$ dan $\mathrm{O}_{3}$ selama 168 jam mengalami penurunan. Kandungan tertinggi dicapai oleh parameter $\mathrm{PM}_{10}$ sebesar $213,47 \mu \mathrm{g} / \mathrm{m}^{3}$ pada jam 10.00. Tingginya kadar $\mathrm{PM}_{10}$ (debu) dipicu dari padatnya aktivitas manusia pada jam tersebut dan juga kegiatan industri yang sangat banyak jumlahnya

di Kota Surabaya, sehingga memicu tingginya kandungan debu dalam udara.
Sedangkan kandungan CO selama 168 jam ke depan relatif stabil dan tidak mengalami penurunan seperti pada parameter yang lain. Banyaknya manusia yang beraktivitas dengan menggunakan kendaraan bermotor memicu kandungan $\mathrm{CO}$ di udara tidak mengalami penurunan. Gas buang hasil pembakaran bahan bakar fosil memicu tingginya kadar CO di udara pada jam 07.00-08.00, kandungan $\mathrm{CO}$ yang berasal dari kendaraan bermotor sekitar $52,9 \%$. CO sebagai partikel utama penyebab pencemaran udara di bidang transportasi (Faishol et al., 2020) 


\subsection{Analisis Plot PEB}

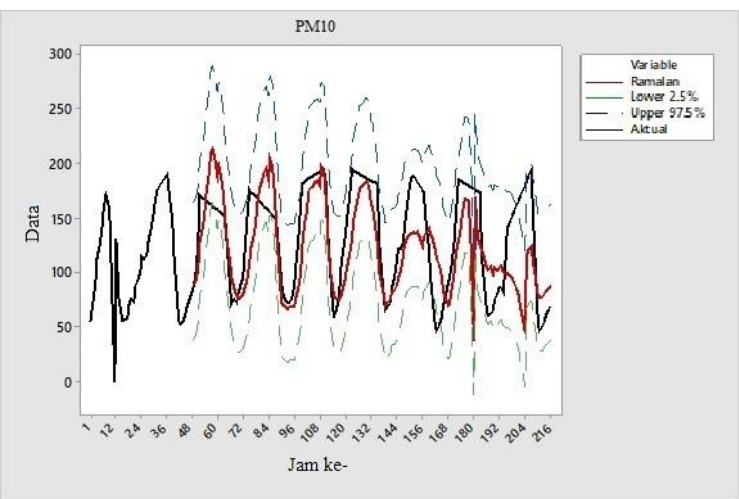

(a) $\mathrm{PM}_{10}$

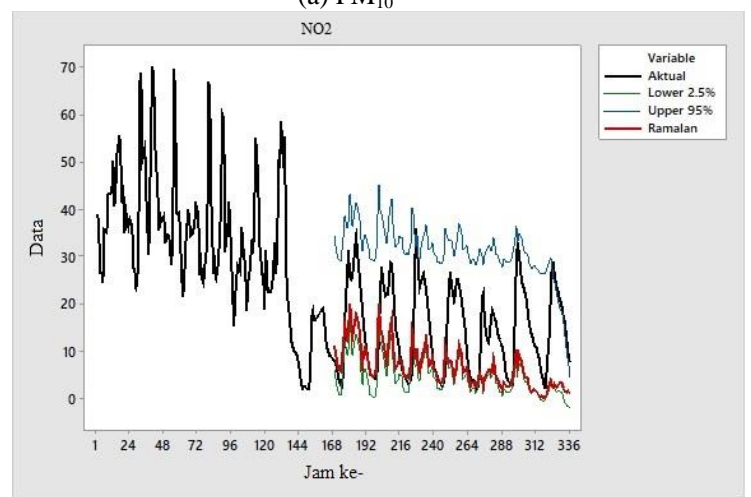

(c) $\mathrm{NO}_{2}$

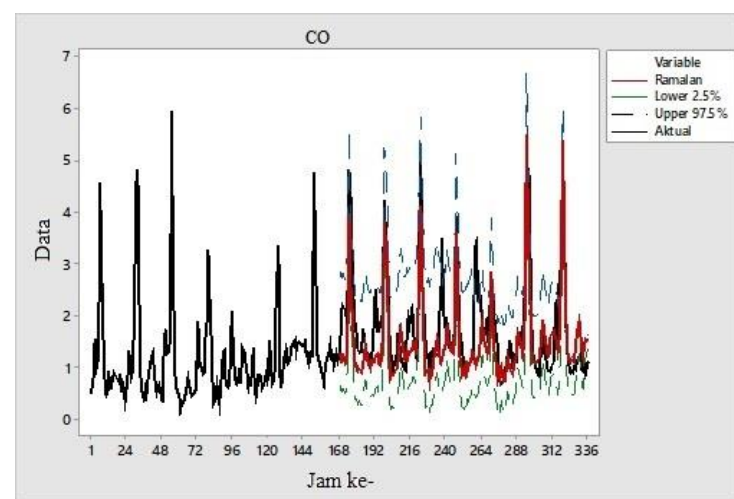

(b) $\mathrm{CO}$

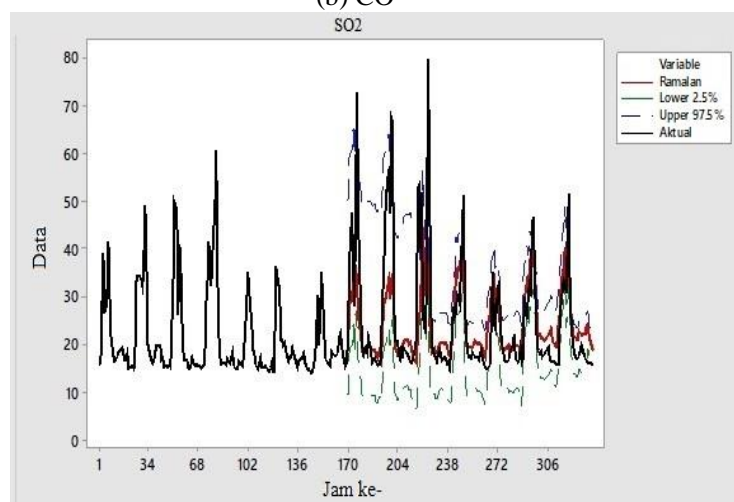

(d) $\mathrm{SO}_{2}$

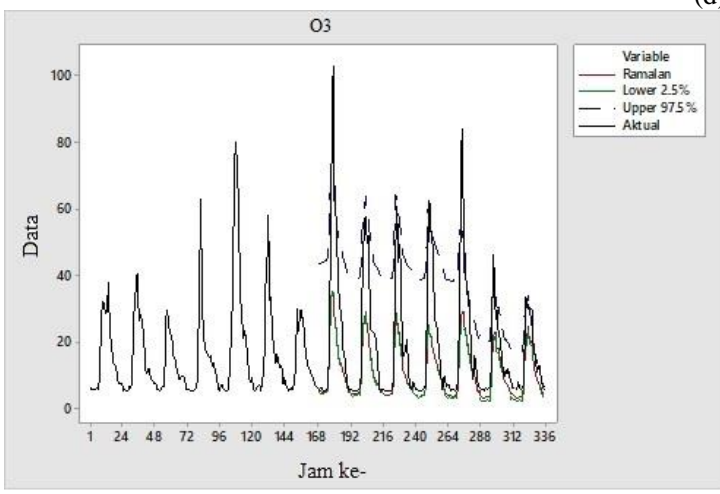

(e) $\mathrm{O}_{3}$

Gambar 2. Perbandingan Plot PEB Data Aktual dengan Data Ramalan

Berdasarkan Gambar 2 plot data PEB masih berada dalam batas atas dan bawah, sehingga dapat disimpulkan bahwa hasil ramalan berdistribusi normal. Selisih antara data aktual dan data ramalan kecil dan plot grafik PEB mengikuti plot grafik di data aktual, sehingga dapat dikatakan bahwa model sudah sesuai.

\subsection{Perhitungan Tingkat Error Hasil Ramalan dengan MAPE}

Berdasarkan hasil perbandingan antara data aktual dengan hasil ramalan dengan menggunakan MAPE, maka diperoleh tingkat error dari tiap parameter yang dapat dilihat pada Tabel 8 .

\begin{tabular}{ccc} 
Tabel 8. Perhitungan & Error Ramalan dengan MAPE \\
\hline Parameter & MAPE & Kategori \\
\hline $\mathrm{PM}_{10}$ & $24,44 \%$ & Layak \\
$\mathrm{CO}$ & $23,89 \%$ & Layak \\
$\mathrm{NO}_{2}$ & $67,57 \%$ & Buruk \\
$\mathrm{SO}_{2}$ & $19,13 \%$ & Baik \\
$\mathrm{O}_{3}$ & $34,25 \%$ & Layak \\
\hline
\end{tabular}

Mean Absolute Percentage Error (MAPE) merupakan salah satu ukuran untuk mengetahui tingkat keakuratan suatu hasil ramalan. Standar pengukuran error berdasarkan MAPE (Nabillah \& Ranggadara, 2020) seperti dalam Tabel 9. 
Tabel 9. Range Nilai MAPE

\begin{tabular}{cl}
\hline Range & \multicolumn{1}{c}{ Keterangan } \\
MAPE & \multicolumn{1}{c}{ Kompetensi Model Peramalan Sangat Baik } \\
\hline $10 \%$ & Kompetensi Model Peramalan Baik \\
$10-20 \%$ & Kompetensi Model Peramalan Layak \\
$20-50 \%$ & Kompetensi Model Peramalan Buruk \\
$>50 \%$ &
\end{tabular}

Hasil peramalan selama 168 jam ke depan dengan tingkat error terrendah dicapai oleh parameter $\mathrm{SO}_{2}$ yaitu 19,13\% dengan kompetensi model peramalan baik. Dari hasil MAPE dapat dikatakan bahwa model yang dihasilkan dapat digunakan sebagai dasar untuk melakukan peramalan jangka pendek terhadap parameter $\mathrm{SO}_{2}$. Sedangkan pada parameter $\mathrm{NO}_{2}$ kompetensi model peramalan adalah buruk. Hal ini menyebabkan model tersebut tidak dapat digunakan untuk melakukan peramalan terhadap parameter $\mathrm{NO}_{2}$ karena menghasilkan error yang sangat besar. Diperlukan model dengan metode yang lain untuk meramalkan parameter $\mathrm{NO}_{2}$. Error yang besar dipicu oleh nilai aktual parameter $\mathrm{NO}_{2}$ yang mempunyai pola volatilitas yang berarti bahwa data pada parameter $\mathrm{NO}_{2}$ mengalami fluktuasi sehingga data tidak stabil karena data mengalami naik turun dari waktu ke waktu yang dipengaruhi oleh banyak faktor misalnya data meteorologi (seperti suhu, radiasi, kelembapan, kecepatan dan arah angin) juga dapat dipicu dari alat pemantauan yang kadangkadang mengalami kerusakan sehingga mengakibatkan perbedaan akurasi alat pemantauan dari jam ke jam.

\section{KESIMPULAN}

Berdasarkan penelitian yang telah dilakukan dapat disimpulkan bahwa:

1. Model terbaik DSARIMA dengan RMSE terkecil 0,59 didapatkan dari parameter $\mathrm{CO}$ yaitu $\operatorname{ARIMA}(0,1,[1,2,3])(0,1,1)^{24}(0,1,1)^{168}$.

2. Hasil peramalan kandungan pencemaran udara berdasarkan lima parameter selama 168 jam menunjukkan kecenderungan mengalami penurunan. Pada parameter $\mathrm{PM}_{10}$ memiliki kandungan tertinggi sebesar $213,47 \mu \mathrm{g} / \mathrm{m}^{3}$ pada jam 10.00 pada waktu pengamatan jika dibandingkan dengan parameter pencemar yang lainnya.

3. Tingkat error terkecil hasil peramalan selama 168 jam berdasarkan MAPE diperoleh dari parameter $\mathrm{SO}_{2}$ sebesar 19,13\% (kategori baik) hal ini berarti bahwa kompetensi model peramalannya sudah sesuai dan dapat digunakan untuk peramalan jangka pendek. Sedangkan untuk parameter lainnya termasuk kategori layak untuk parameter $\mathrm{PM}_{10}, \mathrm{CO}$, dan $\mathrm{O}_{3}$. Sedangkan kategori buruk untuk peramalan $\mathrm{NO}_{2}$, sehingga perlu mencari model peramalan dengan metode yang lain.
4. Penerapan PEB untuk mengukur keakuratan plot peramalan dengan interval antara $2,5 \%$ dan 97,5\% terbukti akurat untuk mengontrol plot data ramalan. Plot data dengan menggunakan pendekatan PEB berada dalam batas atas dan bawah, maka dapat disimpulkan bahwa hasil ramalan berdistribusi normal. Selisih antara data aktual dengan data ramalan kecil dan plot grafik PEB mengikuti plot grafik di data aktual, jadi dapat dikatakan bahwa model sudah sesuai.

\section{DAFTAR PUSTAKA}

ABHILASH, M. S. K., THAKUR, A., GUPTA, D., \& SREEVIDYA, B. (2018). Time Series Analysis of Air Pollution in Bengaluru Using ARIMA Model. Advances in Intelligent Systems and Computing, Vol. 696, Pp. 413426, 413-426.

CHRISDAYANTI, B., \& SUHARSONO, A. (2015). Peramalan Kandungan Particulate Matter (PM10) dalam Udara Ambien Kota Surabaya Menggunakan Double Seasonal ARIMA (DSARIMA). Jurnal Sains Dan Seni ITS, 4(2).

DEEPTHI, L. R., AMRUTA, C. G., KRISHNAN, D., KUMAR, R. S., \& SOURAV, S. (2020). A Novel Approach for Prediction of Air Pollutant Concentration. Proceedings of the 4th International Conference on Trends in Electronics and Informatics, ICOEI 2020, Icoei,

$217-223$. https://doi.org/10.1109/ICOEI48184.2020.914 2907.

DUA, R. D., MADAAN, D. M., MUKHERJEE, P. M., \& LALL, B. L. (2019). Real time attention based bidirectional long short-term memory networks for air pollution forecasting. Proceedings - 5th IEEE International Conference on Big Data Service and Applications, BigDataService 2019, Workshop on Big Data in Water Resources, Environment, and Hydraulic Engineering and Workshop on Medical, Healthcare, Using Big Data Technologies, 151-158. https://doi.org/10.1109/BigDataService.2019.0 0027.

FAISHOL, M. A., ENDROYONO, \& IRFANSYAH, A. (2020). Prediksi Polusi Udara Perkotaan di Surabaya Menggunakan Recurrent Neural Network-Long Short Term Memory. Jurnal Ilmiah Teknologi Informasi (JUTI), 18(2), 102-114.

HAIZUM, N., RAHMAN, A., LEE, M. H., \& TALIB, M. (2019). Hybrid Seasonal ARIMA and Artificial Neural Network in Forecasting Southeast Asia City Air Pollutant Index. 215226.

HAMAMI, F., \& DAHLAN, I. A. (2020). Univariate Time Series Data Forecasting of Air Pollution using LSTM Neural Network. 1- 
5. https://doi.org/10.1109/icadeis49811.2020.927 7393.

MADAAN, D., DUA, R., MUKHERJEE, P., \& LALL, B. (2019). Vayuanukulani: Adaptive memory networks for air pollution forecasting. ArXiv: 1904.03977, 1-5.

MAHAJAN, S., CHEN, L., \& TSAI, T. (2017). An Empirical Study of PM2 . 5 Forecasting Using Neural Network. 2-8.

NABILLAH, I., \& RANGGADARA, I. (2020). Mean Absolute Percentage Error untuk Evaluasi Hasil Prediksi Komoditas Laut. Journal of Information System, 5(2), 250-255. https://doi.org/10.33633/joins.v5i2.3900.

PERATURAN PEMERINTAH REPUBLIK INDONESIA. (1999). Peraturan Pemerintah Indonesia Nomor 41 Tahun 1999 Tentang Pengendalian Pencemaran Udara.

TOMAR, N., PATEL, D., \& JAIN, A. (2020). Air Quality Index Forecasting using Autoregression Models. 2020 IEEE International Students' Conference on Electrical, Electronics and Computer Science, SCEECS 2020.

https://doi.org/10.1109/SCEECS48394.2020.2 16.

TSAI, Y. (2018). Air pollution forecasting using RNN with LSTM. 2018 IEEE 16th Intl Conf on Dependable, Autonomic and Secure Computing, 16th Intl Conf on Pervasive Intelligence and Computing, 4th Intl Conf on Big Data Intelligence and Computing and Cyber Science and Technology Congress(DASC/PiCom/DataCom/CyberSciT ech), 1074-1079. https://doi.org/10.1109/DASC/PiCom/DataCo $\mathrm{m} /$ CyberSciTec.2018.00178.

WAHYU, P. (2018). Pemenuhan Baku Mutu Udara Emisi dan Penangannya; Tinjauan atas Polutan Partikulat, NOx, SO2. Prosiding Seminar Nasional Dan Konsultasi Teknologi Lingkungan, 5(September), 32-41.

ZHU, H., \& HU, J. (2019). Air quality forecasting using SVR with quasi-linear kernel. CITS 2019 - Proceeding of the 2019 International Conference on Computer, Information and Telecommunication Systems, 5-9. https://doi.org/10.1109/CITS.2019.8862114. 